
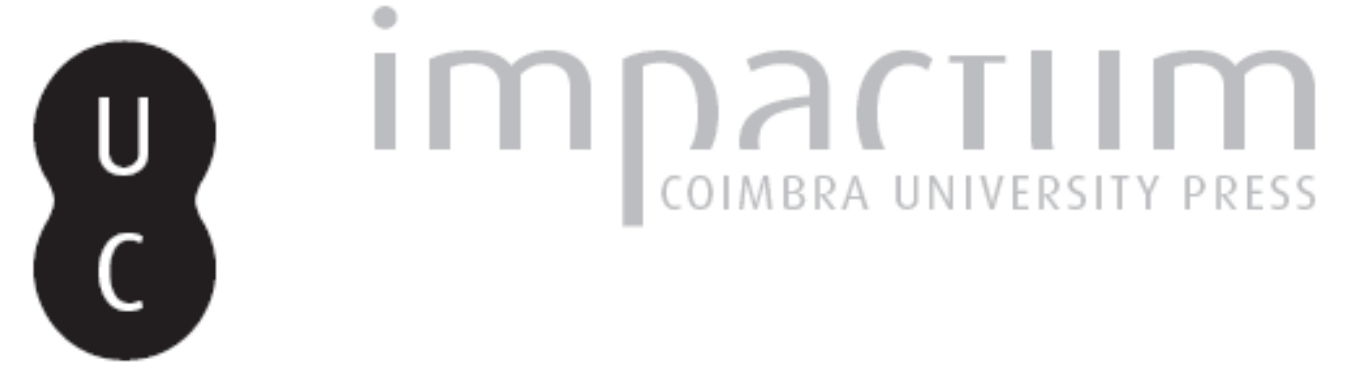

\title{
The politics of the Plinth: notes on a latent ocularcentrism in Aureli's theory of an absolute architecture
}

Autor(es): Laegring, Kasper

Publicado por: Editorial do Departamento de Arquitetura

URL persistente:

URI:http://hdl.handle.net/10316.2/43466

DOI:

DOI:https://doi.org/10.14195/1647-8681_8_9

Accessed : $\quad$ 26-Apr-2023 08:11:05

A navegação consulta e descarregamento dos títulos inseridos nas Bibliotecas Digitais UC Digitalis, UC Pombalina e UC Impactum, pressupõem a aceitação plena e sem reservas dos Termos e Condições de Uso destas Bibliotecas Digitais, disponíveis em https://digitalis.uc.pt/pt-pt/termos.

Conforme exposto nos referidos Termos e Condições de Uso, o descarregamento de títulos de acesso restrito requer uma licença válida de autorização devendo o utilizador aceder ao(s) documento(s) a partir de um endereço de IP da instituição detentora da supramencionada licença.

Ao utilizador é apenas permitido o descarregamento para uso pessoal, pelo que o emprego do(s) título(s) descarregado(s) para outro fim, designadamente comercial, carece de autorização do respetivo autor ou editor da obra.

Na medida em que todas as obras da UC Digitalis se encontram protegidas pelo Código do Direito de Autor e Direitos Conexos e demais legislação aplicável, toda a cópia, parcial ou total, deste documento, nos casos em que é legalmente admitida, deverá conter ou fazer-se acompanhar por este aviso.

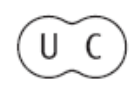




\section{Kasper Laegring \\ 'T'he Politics of the Plinth:}

Department of Arts and Cultural

Notes on a Latent Ocularcentrism

in Aureli's 'Theory of an Äbsolute

\section{Architecture}

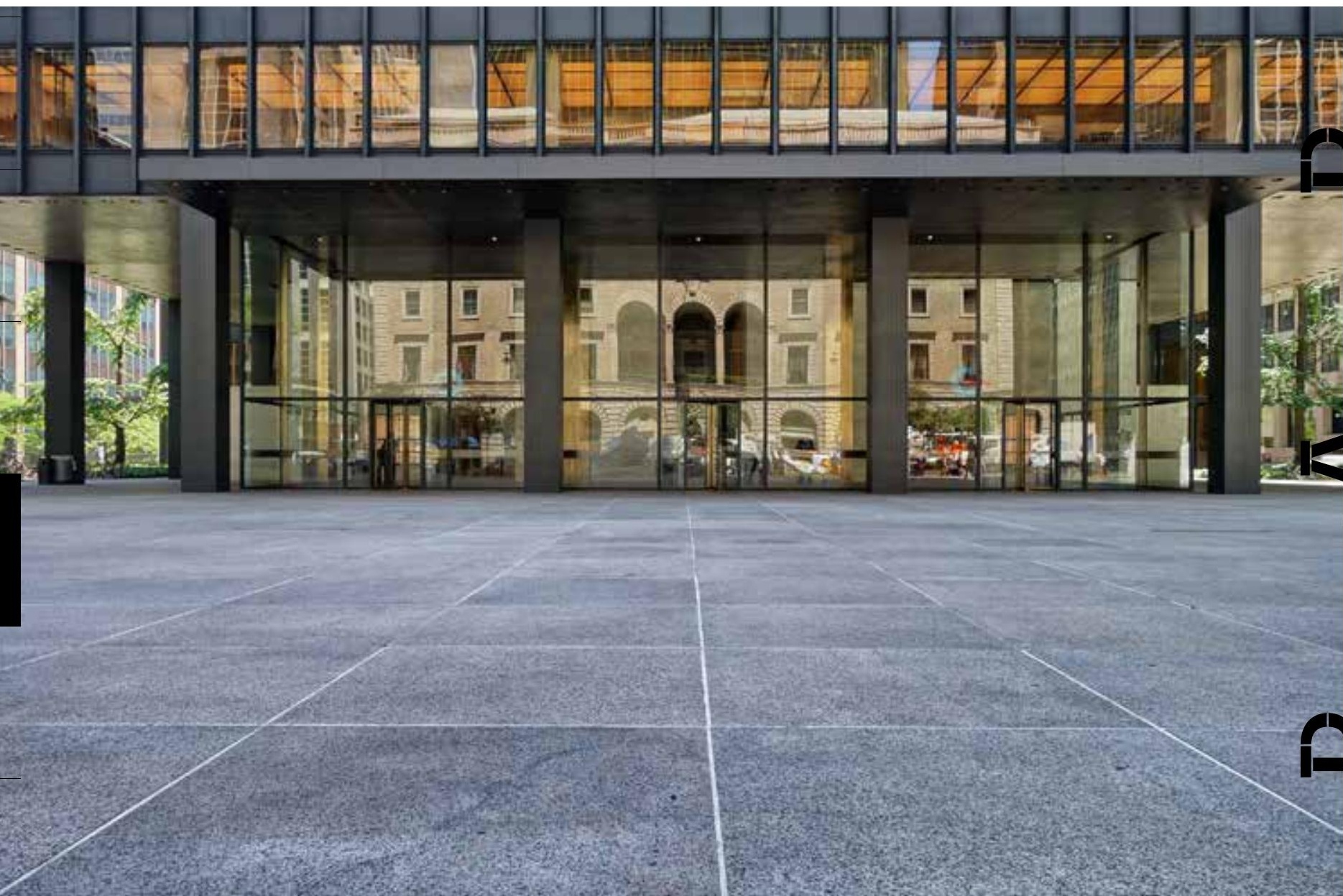




\section{Foreword}

Lately, the issue of architectural form has re-attracted attention from architectural theorists belonging to competing intellectual factions, and a focus on materialism unites many of these efforts. In his influential contribution, Alejandro Zaera Polo dreamt of nothing less than "a political ecology" that would enable "architecture to regain an active political role and overcome the division between nature and politics" (Zaera Polo, 2008, p. 86).

In contrast to Zaera Polo, a different kind of bridging matters to Pier Vittori Aureli, namely the reunification of the domains of urban planning and architecture under the umbrella of form. In the first chapter of Aureli's ambitious contribution to the development of a form-centred architectural theory, The Possibility of an Absolute Architecture (2011), a number of famous urbanists end up on the wrong side of History. Aureli identifies Ildefons Cerdà and Ludwig Hilberseimer with a longstanding modern (and sometimes Modernist) tradition that declares its allegiance to urbanism, not to architecture. Archizoom and Rem Koolhaas, in whose experiments the genericity of urban processes is critically exposed, occupy more ambiguous roles in Aureli's narrative. In contrast, Ludwig Mies van der Rohe emerges as the hero of Aureli's tale, because Mies's built practice fulfils his demand that the production of architectural form be an act of demarcation (Aureli, 2011, p. 41):

Unlike Cerdà, Hilberseimer, Archizoom, and Koolhaas, Mies is concerned not only with the generic quality of this form but also with its limit, with the finitude of its location. Architecture is thus reinvented by absorbing the compulsion to repeat, which is the essential trait of capitalist civilization, while increasing architecture's function as a frame, as a limit both to itself and to the forces and interests it represents.

To Aureli, the defining and limiting effects of architectural form and composition are also what allows a civic and political space to exist at all in today's globalized cities where rational and instrumental economic management (technè oikonomikè) is substituted for politics (technè politikè). Aureli (2011, pp. 29-30) claims that "it is possible to theorize a phenomenological and symbolic coincidence between political action and the making of the form of an object".

The plinth is central to Aureli's analysis of Mies's architecture, because he interprets it as an ideal example of agonistic form which makes possible, firstly, a dialectic of base and building envelope, and, secondly, the emergence of an absolute architecture in the otherwise technocratic modern metropolis. But by elevating the plinth to both a generator of absoluteness and a podium for panoramic viewing, Aureli overlooks the potential impact of ocularcentrism on his theory, I will argue. Furthermore, I hypothesize that this omission puts Aureli's theory
Frontispiece The Seagram Building, New York. Photo: Iker Alsonso. Source: Flickr.

Retrieved from https://www.flickr.com/photos/ finchermac/15174153854/ 
Fig. 1 Ildefons Cerdà, Enlargement map of Barcelona. Map of the neighborhoods of the city of Barcelona and project for its improvements and enlargement, 1859.

Courtesy: Museu d'Historia de la Ciutat, Barcelona. at risk of being enmeshed in a nineteenth-century European urban visual culture that was born out of the very 'museum city' model that he rejects, and which would later evolve into the disciplinary urbanism that he opposes.

Other reviewers of and commentators on Aureli's important tome have reproached Aureli for not exercising sufficient historiographical rigor (Leach, 2012) and for crafting a concept of ascetic minimalism that remains complicit in neo-liberalism in spite of the author's intentions (Spencer, 2017), while others have interpreted Aureli's project as a renewed interest in monumentality and as a promotion of architectural form as a tool for collective, civic anamnesis (Fowler, 2009).

In this article I will follow a different intellectual trajectory, focusing instead on the lack of attention given to the impact of visual culture on the disciplinary city of the second half of the nineteenth century in The Possibility of an Absolute Architecture. In the words of Christine Boyer, architecture and the "arts still carry within their visual imaginations the influence of nineteenth-century procedures and representational views of city building" (Boyer, 1994, p. 1), and even Aureli's theory cannot entirely escape this paradigm, I will argue.

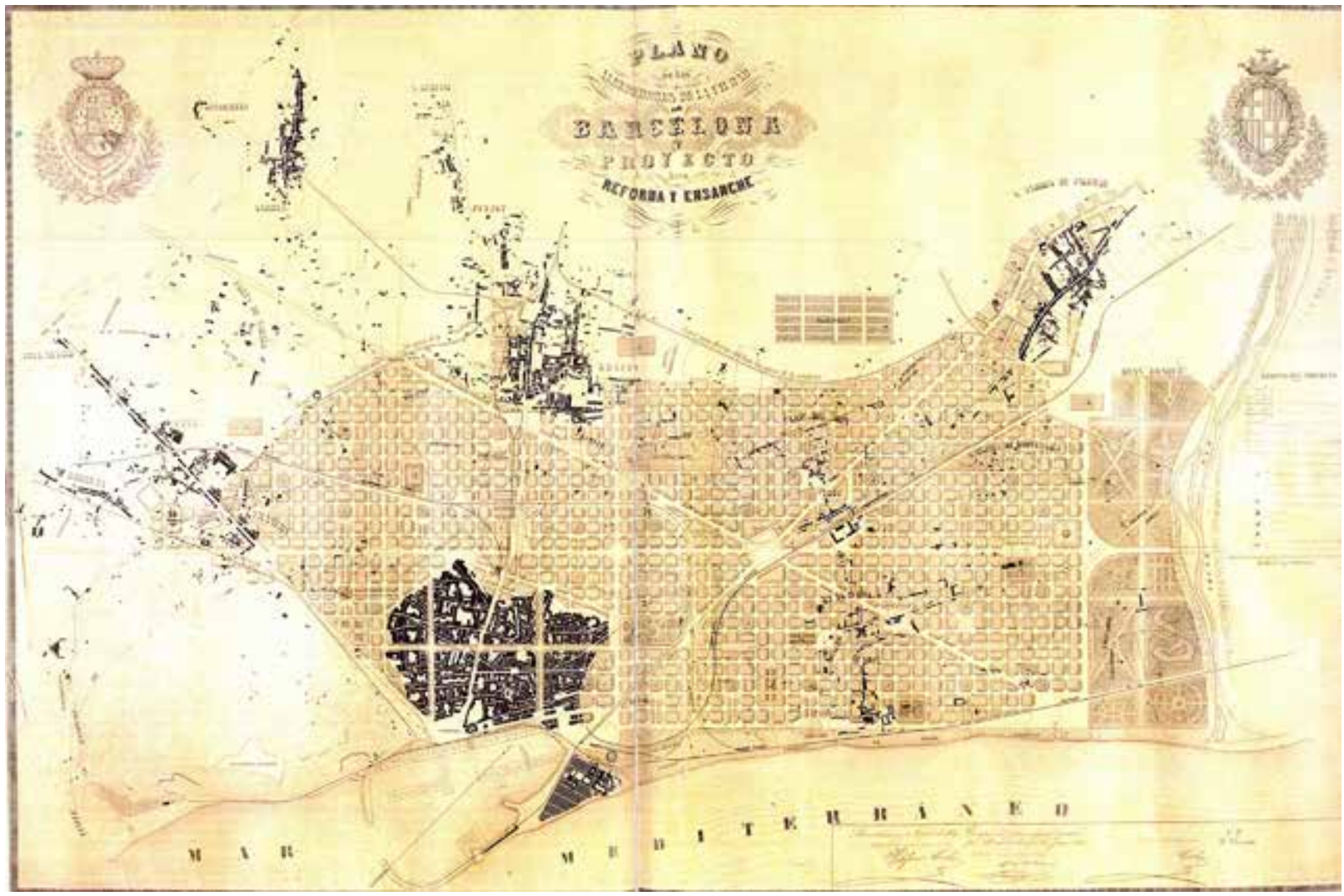




\section{The dialectic of urban form: Aureli's theory of insular and agonistic form}

Aureli outlines a historical narrative of the European city anchored in philosophical, judicial, and technological events, all of which have led to the present predicament where cities are no longer shaped by architects, but by professional managerial urbanists. According to Aureli (2011, p. 9), urbanism has long been the archenemy of architecture, but its current breed came into being with Ildefons Cerdà's enlargement of Barcelona (the Eixample, 1859), followed by his Teoría general de la urbanizacion (1867) as its theoretical groundwork.

Gradually, Aureli argues, economy and management have triumphed over politics exactly because of their embeddedness in the urban infrastructure. He traces the emergence of this development back to a fundamental divide between Ancient Greek and Ancient Roman conceptualizations of the city: the polis versus the urbs; the city-state versus the empire. This divide is again mirrored in the legal systems of these civilizations, where Aureli - by forging an unusual alliance of political and ethical concepts derived from Hannah Arendt and Carl Schmitt - contrasts nomos with lex.

At the end of his book, Aureli has made a giant leap through history, discussing now how the 'archipelago' model was taken up by Oswald Mathias Ungers et al. in their proposal for Berlin as a Green Archipelago (1977). This project is exemplary to Aureli, because, here Ungers envisions the city as an archipelago - as 'cities within the city' or 'a city made by islands', and in that sense, no singular typological principle is allowed to attain universal status, nor to become the basis for a utopian model (such as Hilberseimer's infamous Groszstadt Architektur proposal, 1927).

Within this 'archipelago', form is understood as insular, limiting, and agonistic. A dialectic emerges, both between the form-object and its surrounding urban environment and within the form-object itself, where the act of composition governs this duality.

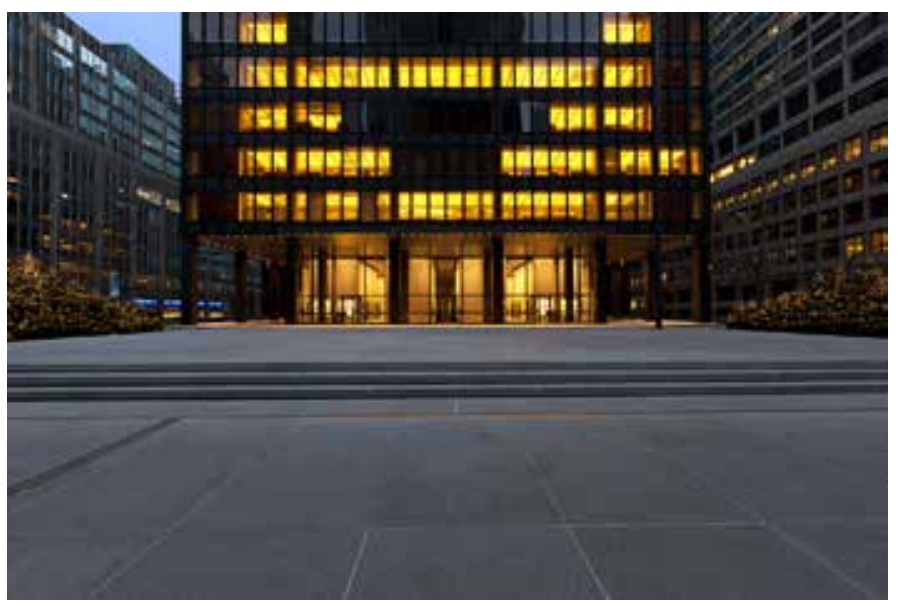

Fig. 2 The Seagram Plaza.

Photo: Joseph Buxbaum. Source: Flickr. Retrieved from https://www.flickr.com/ photos/91260116@N04/8335131757/ 


\section{Mies's plinth as a state of exception}

Ludwig Mies van der Rohe enters into Aureli's project because he never produced a systematic urban theory, unlike his compatriot and friend, Ludwig Hilberseimer. Aureli (2011, p. 36) aims to deliver a different reading of Mies van der Rohe's production than the one which dominates the reception of Mies's oeuvre. In other words, he is not searching for critical autonomy in Miesian 'silence', such as K. Michael Hays (1984), nor is he preoccupied with themes such as aesthetic minimalism, modularization, tectonic culture, or industrial mass production; what he instead proposes is to regard Mies's employment of the plinth in several works - Riehl House near Potsdam (1907), the Barcelona Pavilion (1929), the Seagram Building in New York (1954-58), and the Neue Nationalgalerie in Berlin (1962-68) - as a way forward towards the founding of a theory of 'absolute architecture'.

In spite of its North American (and global) offspring, I will treat this plinth-plus-pavilion model as essentially European, because Aureli's analysis of the Seagram Building treats the footprint of the high-rise as an anomaly of space management in the pattern of the New York grid.

In emphasizing the bodily experience of a momentary disconnect from the forces of urbanization when "climbing a Mies plinth", Aureli inadvertently celebrates the temple-like quality of these plinths, and he describes his experience as being of the same quality, whether in $\mathrm{New}$ York or in Berlin (Aureli, 2011, p. 37). Whereas other theorists (Westheim, 1927; Johnson, 1979; Bergdoll, 2001; Stemshorn, 2002) have interpreted Mies's architectural project as a reformulation of a tectonic logic that would make Mies the successor not only to the builders of the Ancient Greek temple, but also to Karl Friedrich Schinkel, Aureli avoids such a poetics of the tectonic, and instead interprets the plinth as the 'classical' part of an architectural composition, where the building envelope has a different, more industrial, more artificial and more generic, origin than its base. He also bypasses any parallelization of the two architects' employment of frontality and axiality.

Fig. 3 The Seagram Plaza.

Photo: Joseph Buxbaum. Source: Flickr. Retrieved from https://www.flickr.com/ photos/91260116@N04/8335144585/

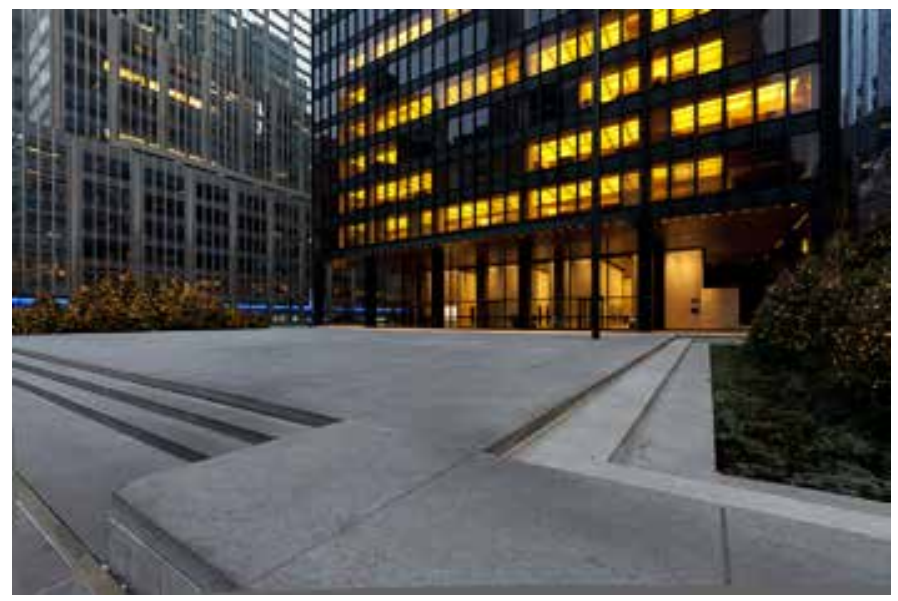




\section{Reprogramming the plinth}

Aureli proposes not only a dialectic between the 'islands' and the entire 'archipelago', but also a dialectic between the building's base, its plinth, and its building envelope. Yet Aureli's dialectic only engages the exterior of the building. For some reason - maybe the lack of interest in functional program - Aureli's otherwise passionate exploration never takes him inside the Seagram.

It has not gone unnoticed by reviewers that "Aureli's methodology appears out of sync with his political motivations to block the circulatory mechanisms of urbanism, as anyone who has stood in front of van der Rohe's corporate palaces at Seagram or TorontoDominion will recognize immediately" (Diamanti, 2012, p. 2). However, as Jeff Diamanti points out next, such a critique would amount to a misreading of Aureli's undertaking of "the autonomy of the project" (Aureli, 2011, p. xiii), since Aureli's theory specifically allows for an understanding whereby form is not reducible to the (capitalist) conditions of its making.

What Aureli seems to share with the tectonic school of thought, such as Kenneth Frampton's, is the demand of visibility, of appearing, of the manifestation of certain innate principles in the physical and material structure of the work of architecture (Weiner, 1996, p. 502). "The forces of urbanization are made explicit", Aureli (2011, p. 40) writes, arguing that "the forces of urbanization in the form of the mass production of building technology" becomes "the very appearance" (Aureli, 2011, p. 34) of Mies's architecture (see also p. 212 in regards to Ungers). This optic dimension also pervades Aureli's description (Aureli, 2011, p. 37) of his own experience of Miesian architecture:

One of the most remarkable things felt by anyone climbing a Mies plinth, whether in New York or in Berlin, is the experience of turning one's back to the building in order to look at the city. Suddenly, and for a brief moment, one is estranged from the flows and organizational patterns that animate the city, yet still confronting them.

The reinterpreted plinth facilitates the emergence of a novel visual culture, and one is reminded of Karl Friedrich Schinkel's 1829 perspective drawing of his projected main staircase in the stoa of the Altes Museum in Berlin (1823-30) where Schinkel has turned his back on the museum in order to show us, in one image, both the panorama of the Berlin skyline framed by two rows of Ionic columns, and the series of mythological frescoes welcoming the visitor. Christine Boyer (1994, p. 102) regards this structure as a decisive turning point in the history of urban culture, since Schinkel here not only combines classical spatial motifs in order to shape an entirely new institution, the public art museum; he also turns his edifice into one end of a powerful visual dialectic between building and city: 
Fig. 4 Karl Friedrich Schinkel, Altes Museum, Berlin, view from the main staircase toward the city, 1829. Engraving by Hans Fincke, from Sammlung architektonischer Entwürfe 17, no. 103 (Berlin: Wittich, 1831).

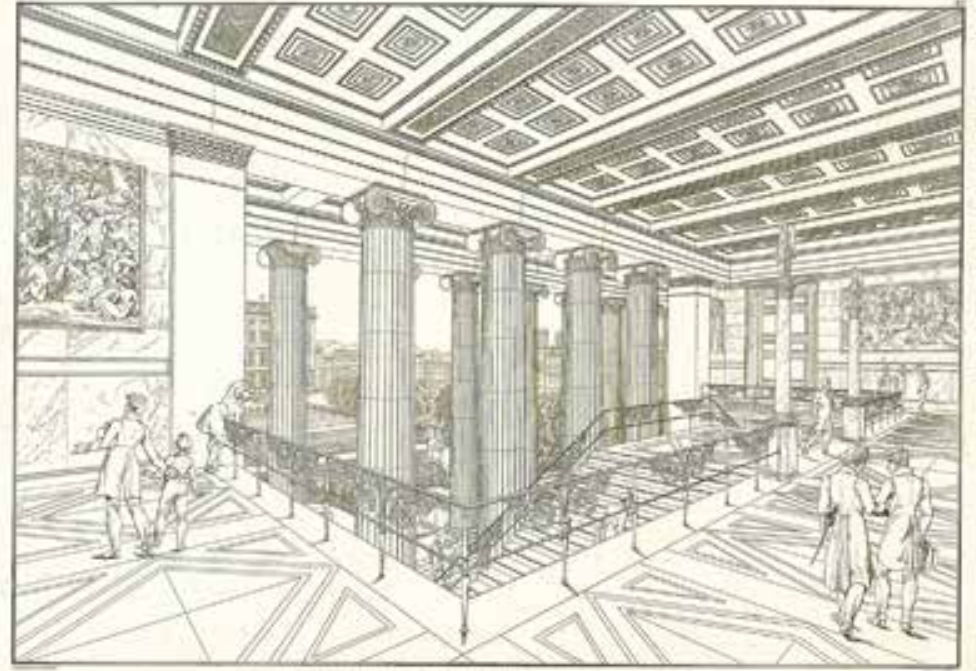

Fig. 5 Alte Nationalgalerie, Berlin.

Photo: Thomas Wolf, www.foto-tw.de.

Source: Wikimedia Commons. Retrieved from

https://commons.wikimedia.org/wiki/File:Alte_

Nationalgalerie_abends.jpg
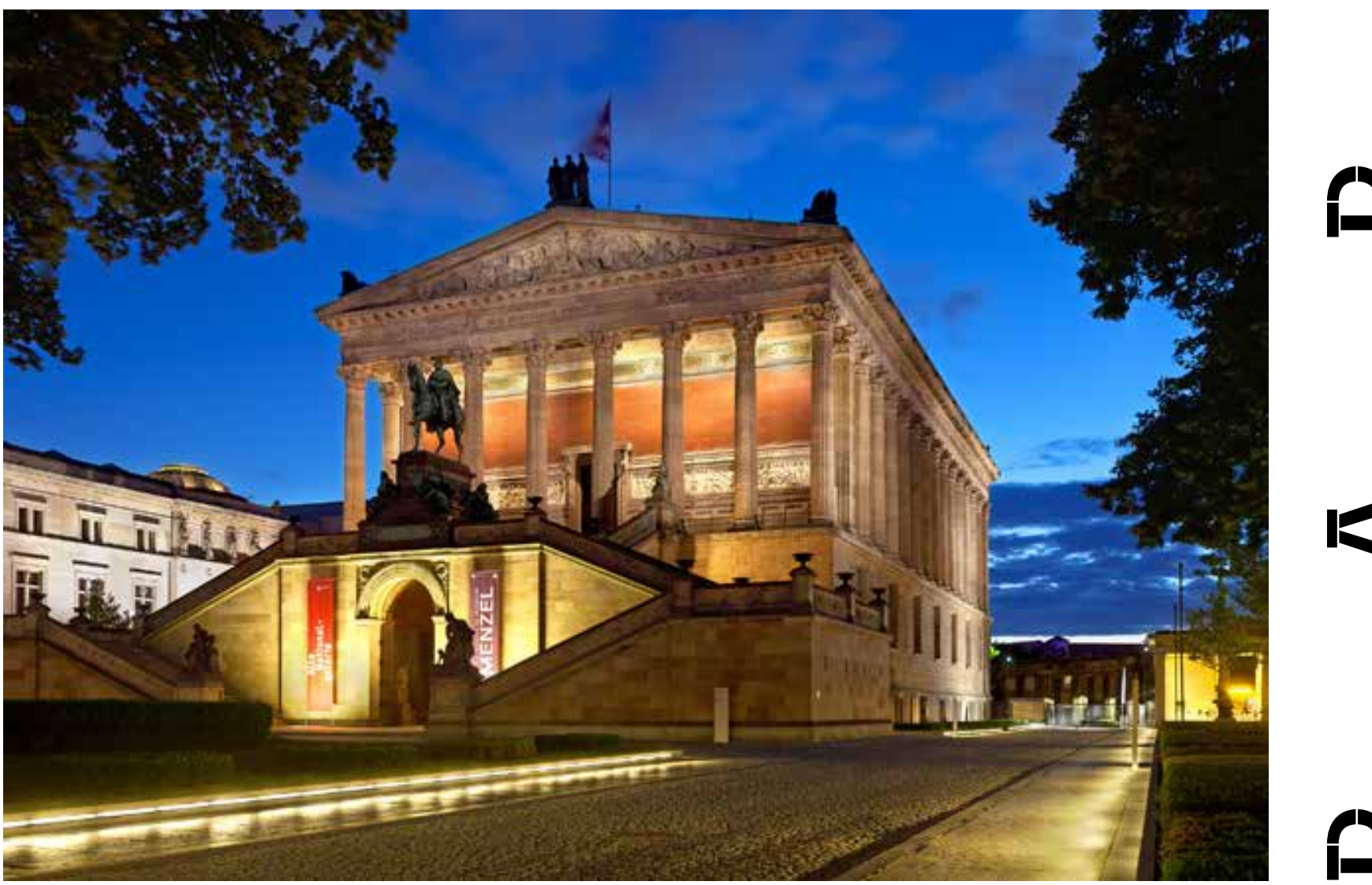
In Schinkel's work the perspectival stage had reached its ultimate achievement: the scenographic arrangement of the modern city.

Just like its supported glass pavilion, Mies's plinth in Berlin is much more omnidirectional than Schinkel's receptacle, and Mies's museum on the Culture Forum suggests no privileged direction for looking, nor does its plinth frame the visitor's visual perception. Nonetheless, Aureli's flashback to his experience on the various plinths can only be understood as his tacit acceptance of an urban visual culture in which buildings function not only as 'absolute' works in their own right, but also as means of activating the enjoyment of the city as spectacle.

Aureli's understanding of the plinth as a vast podium that enables spectatorship is alien to its documented use in the Ancient Greek temple, where the plinth was subjected to optical, illusionistic refinements (Penrose, 1888: Goodyear, 1912) that certainly evidence a sophisticated beholder orientation, but whose function had no relationship to the city whatsoever.

\section{The city-as-museum}

Incidentally, the receptive structure of Schinkel's pioneering museum edifice in the heart of Berlin betrays Aureli's theory by its lack of clear boundary between inside and outside; in other words, because of its spatial osmosis. The stairwell is opened up, both in order to receive the flow of visitors and to allow for a framing of the urban panorama from a perspective deep within the building volume.

To Schinkel, the didactical framing of this urban panorama made it inseparable from Bildung, and hence a radically new idea of the modern city as the sum of vistas and visual exchanges was born. As Schinkel anticipated with his innovative structure in Berlin, a cultural building could both serve the masses (by being physically opened up), act as an iconic point de vue, and itself be a framing device - all at one and the same time.

Aureli contrasts his favourite, Ungersian model of the "city within the city' with the 'collage' model promoted by Colin Rowe and Fred Koetter in their manifesto Collage City (1978), which Aureli critiques for being merely an instantiation of aestheticism and subjective cultures of taste, not a true dialectic between separate urban typologies in an 'archipelago' (Aureli, 2011, pp. 205-206; 212).

Although history and collective memory each play important parts in the background of Aureli's theory, he does not approve of Rowe and Koetter's infatuation with "a recurrent, and maybe not a repressive, nineteenth century theme: the city as museum". According to the two authors of Collage City (Rowe and Koetter, 1978, p. 126),

The city as museum, the city as a positive concert of culture and educational purpose, the city as a benevolent source of random but carefully selected information, was perhaps to be most abundantly realized in the Munich of Ludwig I and Leo von Klenze. 
Schinkel's art museum next to the Lustgarten in Berlin belongs to this tradition, and by unknowingly subscribing to a novel visual culture that was born out the very 'city-as-museum' model for which Rowe and Koetter advocate, Aureli ends up trading one nineteenthcentury invention for another. For although Rowe and Koetter abhorred totalizing urban interventions such as Wiener Ringstraße and Baron Haussmann's surgical incisions in the urban fabric of Paris, their favorite Klenzian model would eventually lead to such urban precepts.

Fig. 6 Wiener Ringstraße, view toward the Parliament Building. Print no. 6444,

Detroit Publishing Company, 1905.

Source: Library of Congress.

Retrieved from https://commons.wikimedia.org/ wiki/File:Parliament,_Vienna,_Austro-HungaryLCCN2002708394.tif

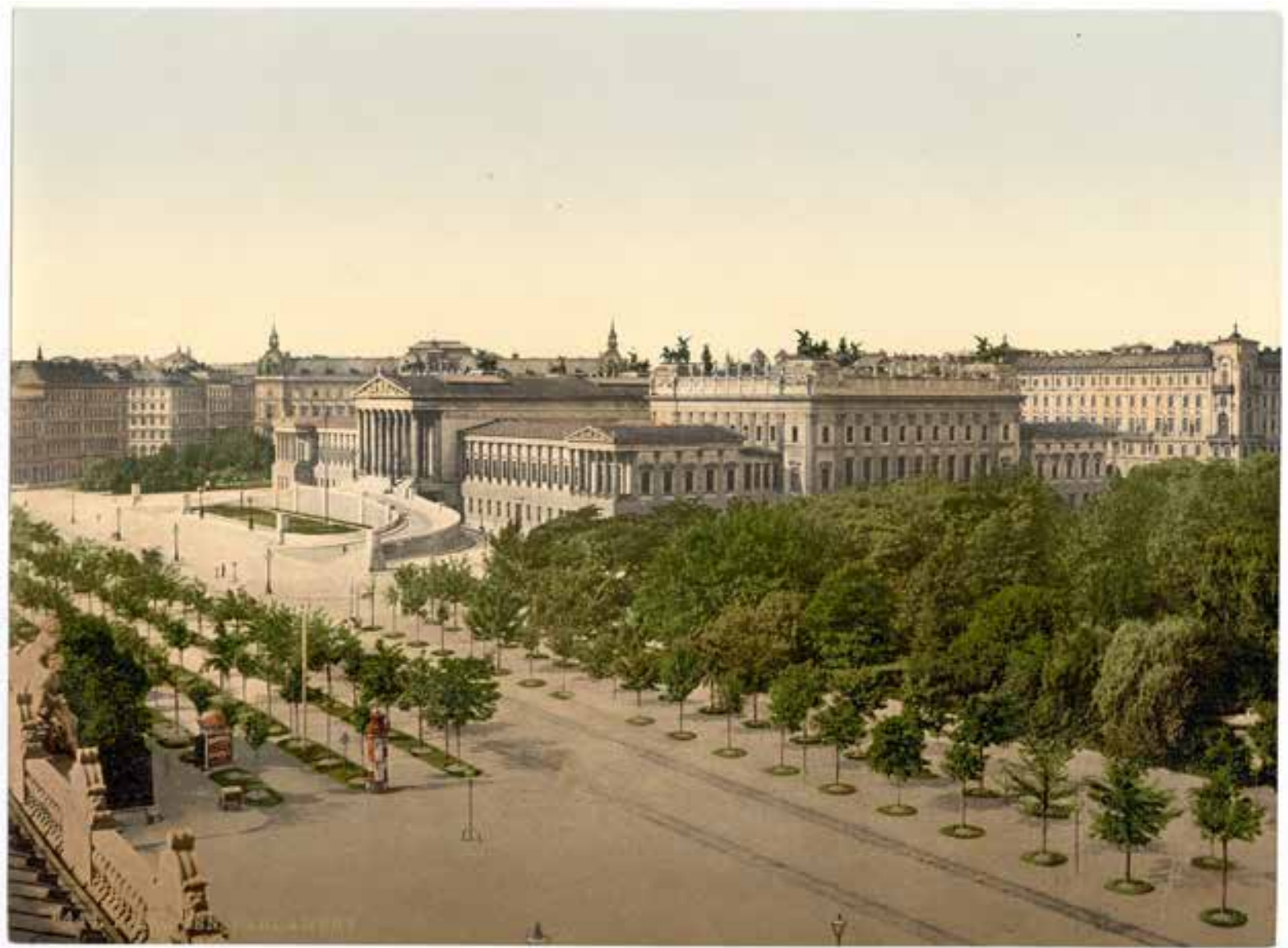




\section{The visual culture of the disciplinary city}

While Aureli's historical analysis of the birth of the managerial dimension of the phenomenon of nineteenth-century disciplinary urbanism is to-the-point and more relevant than ever, it lacks its logical counterpart, namely an analysis of the visual culture of the disciplinary city.

As Camillo Sitte's critique of his contemporary city already evidences (Sitte, 1889), urbanistic schemes such as the Wiener Ringstraße were just as much the seeds of a new, panoptical visual culture as they were enablers of a new managerial practice in the city. Corinne Fournier (2005) has argued that the modern disciplinary city

- Vienna, Barcelona, Paris - came into being through the threefold strategy of, firstly, the creation of vast, uniform spaces for transportation and commerce; secondly, the revivalist and eclectic use of historical styles; and lastly, the strive toward a transparent architecture. All of these aspects were active in shaping a new urban visual culture, parts of which live on until the present day.

As Fournier explains, the strategic and spectacular use of stylistic motifs from ossified cultures performed a necessary compensatory and reassuring cultural function in a city whose citizens were facing constant, massive changes in financial security, technological innovation, ways of living, and speed of perception. As many perceptive cultural critics of the era witnessed, the intensification of historicism masked the instability and flux of the new urban lifeworld. Hence the 'museum city' model came to the rescue (Fournier, 2005, p. 158):

As a result of these developments, historicism went hand in hand with a disciplinary mentality. Under the cover of restoring continuity with a lost tradition, it manipulated the past, archived it, museified and froze it in stereotypical forms that were juxtaposed according to a visual and well ordered scenography.

Just like Aureli, Fournier also regards the nineteenth-century city as an environment where every activity is programmed to accelerate productivity. The surveillance component of modern society, theorized by Michel Foucault, was enhanced and extended into the actual urban space of boulevards and transparent public buildings of iron and glass, while at the same time the citizen gained a new possibility of himself or herself exerting a panoptic gaze. Visual mastery and spectatorship are thus indispensable to the functioning of this urban model:

The ideal of the disciplinary is that of a city of pure vision: a city that not only gives more importance to vision than to the other senses, but also one that favors the development of an abstract and intellectual vision to the detriment of a subjective and memorial one. There is, in short, a predominance of the optical over the tactile (Fournier, 2005, p. 161). 
Let us have a look at an example of a public, monumental building from this epoch beyond the provincial 'museum city'. With the Alte Nationalgalerie (1867-76), also located on the Museum Island in Berlin, architect Friedrich August Stüler faithfully recreated an octastyle Corinthian temple of the Roman type, but continued Schinkel's innovative practice of motivic and typological combinatorics. Here a grand ceremonial staircase, supporting an equestrian statue of King Frederick William IV of Prussia, has been attached to this new 'temple of the arts', allowing both for a solemn entry experience, for sequential panoramic viewing of Berlin, and for patriotic nation-building.

\section{Absoluteness of form, ubiquity of ocularcentrism}

All differences aside, the Seagram Building showcases the same innovative combination of architectural elements as the Altes Museum and the Alte Nationalgalerie. It is precisely the unusual hybrid project of a modern, rational, and dematerialized office tower and an ancient, cultic, and solid supporting base that draws Aureli's attention to this exemplum, for "the very condition of architectural form is to separate and to be separated" (Aureli, 2011, p. ix).

Analysing the impact of Palladio, Aureli praises the architect's "subtle references to ancient typologies" and he concludes that "the power of the exemplum resides in its ability to propose a general paradigmatic framework rather than a set of regulations or commands to be literally deployed" (Aureli, 2011, p. 82). In this way, Aureli distances himself from the orthodoxy of rules of proportion.

Matters of form, composition, materiality, orientation, spatiality, and program emerge from these pages as the latent means by which architecture might make some claim upon the city on its own terms.

Leach's summary (2012, p. 38) contains the clue to the problem that I am addressing here: Aureli seems to insist that the plinth of the Seagram can perform the same exceptional quasi-political function as a plinth from any other time period. In other words, he values the eternal and abstract potential of form for territorial demarcation and political agonism over the historicity of form. This problematic divide is already evident when Aureli, as we recall, wants to arrive at a "phenomenological and symbolic coincidence" between the formal and the political. This leads to a situation where Aureli builds upon a Foucauldian line of thought as regards the managerial disciplinary nature of the modern metropolis (Aureli, 2011, p. 10, n. 23; 160) but at the same time downplays the historicity of architectural form and space, which are delivered into strictly phenomenological hands.

This split between historically structured society and transcendent form allows Aureli to claim "that architecture can act politically without (necessarily) being a tool of politics" (Leach, 2012, p. 39). Aureli thus imbues a particular kind of form with the potential to occupy a 
position not only outside of capitalist hegemony, but also outside of history altogether, for the politically performative potential of formal demarcation seems to remain unchanged throughout history.

But just as in the case of the Alte Nationalgalerie, the structure in question is no longer what it used to be. In Berlin, we no longer face a Baroque staircase; we encounter a structure in the service of not only a sovereign, but also of a city, of a nation-state, and of an emerging empire. In New York, we no longer face an Ancient Greek plinth, but a modern reinterpretation of it, servicing a completely novel type of building.

That the true nature of the modern metropolis can only be revealed at a distance, in the act of stepping out of the crowds, raising oneself above the bustling streets and gaining panoptical overview, is not a new desire. Its most extreme manifestation is to be found in Michel de Certeau's critique of ocularcentrism, where scopic desire is famously embodied in the Icarian archetype of the city planner, who gains visual gnosis at the expense of being able to take part in everyday urban life (Certeau, 1984, p. 93):

The panorama-city is a "theoretical" (that is, visual) simulacrum, in short a picture, whose condition of possibility is an oblivion and a misunderstanding of practices.

In a recent essay Aureli discusses the ideological reorientation heralded by French President François Mitterand's Grands projets of the 1980 s, and here he voices a clear and critical stance on the culture of spectacle first theorized by Guy Debord (Aureli, 2015, p. 51):

Culture, creativity, social exchange - the entire life of the metropolis - were no longer phenomena beside work, but the core potential for production. [...] Mitterand's Grands projets can be understood as a first attempt to put to work the urban spectacle in order to define a new metropolitan subjectivity.

Thus, there can be no doubt that Aureli regards this modern culture of spectacle as a result of the very forces of urbanization that he problematizes, and my aim here is not to reproach Aureli for being unable to annul a visual paradigm that came into existence in the nineteenth century, and which still exerts influence on urban design (Boyer, 1994). Just as Aureli makes no claim to be able to halt global capitalism, I make no claim to be able to step out of this pervasive visual culture. Even in one of the major critiques of ocularcentrism in architecture, we find praise for the same visual arrangement that attracts Aureli's interest (Pallasmaa, 2005, p. 29):

In Mies van der Rohe's architecture a frontal perspectival perception predominates, but his unique sense of order, structure, weight, detail and craft decisively enriches the visual paradigm. 
Rather, my ambition is to demonstrate that the managerial and the representational aspects of urbanism are interwoven and that the quarantining of the one aspect through formal practice does not necessarily lead to the suppression of the other. And since Aureli (2011, p. 44) openly rejects the legitimacy of the iconic building, it seems relevant to ask of his theory what impact the visual paradigm of disciplinary urbanism has on 'the possibility of an absolute architecture'. While the spectacular effect of the iconic building is easily identifiable, it requires closer inspection to unravel the visual exchange in which an edifice very often the art museum - has become "a machine for looking" (Baume, 2006, p. 118) that feeds on the attractions and centrality of the city. This contemporary visual correlate of managerial urbanism has recently been characterized as a culture generating a "stunned subjectivity and arrested sociality supported by spectacle" (Foster, 2011, p. xii).

\section{Conclusion}

Being a thematic collection of essays in 'operative criticism', The Possibility of an Absolute Architecture ends without a proper conclusion, and in this article I have attempted to fill out some of the gaps, primarily by shedding light on the latent - but very significant - operation of visual culture in Aureli's theory, which notably excludes nineteenthcentury architects from its pantheon, but which remains affected by the spatial and representational models of this epoch nonetheless.

Aureli might leave the physical infrastructure of the city behind when climbing Mies's plinth, but in that very instance he enters into a particular visual culture, European in origin, which is the symbolic and representational counterpart to the material workings of urbanism that he has comprehensively analysed. And the fact that Aureli's theory ends up being inadvertently implicated in nineteenth-century visual culture suggests that even the most 'absolute' piece of Modernist architecture partakes in the "drama of architecture's own dissolution into the mediatic matrix", if we follow Reinhold Martin's (2001, p. 67) experience of the Seagram Building. What I thus hope to have demonstrated is the fact that even the most hard-headed materialist conceptualization of the European city has difficulty in leaving behind a visual culture that was just as much implicated in the birth of urbanism as Cerdà's revolutionary expansion of Barcelona.

This is not to say that I believe that Aureli's omission positions his scholarship within a scopophilic regime; quite the contrary. His book indicates rather an adherence to a hermeneutic paradigm built upon words, not images. Martin Jay has noted that "we have increasingly come in the twentieth century to distrust perception in general and vision in particular as the ground of knowledge, often turning instead to language in all its various guises as an alternative" (Jay, 1988, p. 318), and Aureli's work is no exception from this tendency.

Neither do I believe that an exit from the visual paradigm of the disciplinary city and a reformation of urban visual culture are easily 
found. "The city is not a post-card", Alberto Pérez-Gómez (2007, p. 43)

exhorts, objecting to "context as an objectified, picture-like lifeless form". But as this quotation implies, the mechanisms supporting the urban spectacle were never architectural only, but belong to a wider culture of technology and representation far beyond the command of architects, let alone professional urbanists.

\section{References}

Aureli, P. V. (2011). The Possibility of an Absolute Architecture. Cambridge, MA: The MIT Press.

-

Aureli, P. V. (2015). Architecture and

Counterrevolution: OMA and the Politics of the Grands projets. OASE, 94, 44-52.

-

Baume, N. (2006). It's Still Fun to Have Architecture: An interview with Elizabeth Diller, Ricardo Scofidio, and Charles Renfro. In Nicholas Baume (Ed.). Super Vision: Institute of Contemporary Art/Boston (pp. 178-191). Cambridge, MA: The MIT Press.

-

Bergdoll, B. (2001). Mies and Schinkel: nature and consciousness in the modern house. In Susan M. Peik (Ed.). Karl Friedrich Schinkel: Aspects of his Work: Aspekte seines Werks (pp. 125-135). Stuttgart \& London: Edition Axel Menges.

Boyer, M. C. (1994). The City of Collective Memory: Its Historical Imagery and Architectural Entertainments. Cambridge, MA: The MIT Press.

-

de Certeau, M. (1984). The Practice of Everyday Life. Berkeley and Los Angeles: University of California Press.

-

Diamanti, J. (2012). Architectural Positions [review of The Possibility of an Absolute Architecture]. Reviews in Cultural Theory, 3(1), 1-5.

Foster, H. (2011). The Art-Architecture Complex. London \& New York, NY: Verso.

Fournier, C. (2005). The Disciplinary City in the Second Half of the Nineteenth Century. In David Spurr and Cornelia Tschichold (Eds). The Space of English (SPELL: Swiss Papers in English Language and Literature, 17) (pp. 153-162). Tübingen: Gunter Narr Verlag.
Fowler, J. (2009). Agonism, Consensus, and the Exception: On the Newest Monumentalists. Proceedings of the 4th International Conference of the International Forum on Urbanism: The New Urban Question - Urbanism beyond Neo-Liberalism, 627-636.

Goodyear, W. H. (1912). Greek Refinements: Studies in Temperamental Architecture. New Haven: Yale University Press.

Hays, K. M. (1984). Critical Architecture: Between Culture and Form. Perspecta, 21, 14-29.

-

Jay, M. (1988). The Rise of Hermeneutics and the Crisis of Ocularcentrism. Poetics Today, 2, 307-326.

-

Johnson, P. (1979). Schinkel and Mies [1961]. In Philip Johnson. Writings (pp. 161-181). New York: Oxford University Press.

-

Koolhaas, R. (1995). Bigness, or the problem of Large [1994]. In Jennifer Sigler (Ed.). Small, Medium, Large, Extra-Large: Office for Metropolitan Architecture: Rem Koolhaas and Bruce Mau (pp. 494-517). New York, NY: The Monacelli Press.

\section{-}

Leach, A. (2012). The Possibility of an Absolute Architecture [book review]. Journal of Architectural Education, 66(1), 38-39.

Martin, R. (2001). Atrocities. Or, Curtain Wall as Mass Medium. Perspecta, 32, 66-75.

Pallasmaa, J. (2005). The Eyes of the Skin: Architecture and the Senses. London: Wiley.

-

Penrose, F. C. (1888). An Investigation of the Principles of Athenian Architecture: Or, The Results of a Recent Survey Conducted chiefly with Reference to the Optical Refinements Exhibited in the Construction of the Ancient Buildings at Athens. London: Macmillan.
Pérez-Gómez, A. (2007). The City is not a Post-Card: The Problem of Genius Loci. Arkitektur N, 4, 42-47.

Rowe, C. \& Koetter, F. (1978). Collage City.

Cambridge, MA: The MIT Press.

Sitte, C. (1889). Der Städtebau nach seinen künstlerischen Grundsätzen. Wien: Verlag Carl Graeser.

Spencer, D. (2017). Less than enough: A critique of Aureli's project. In Teresa Stoppani, Giorgio Ponzo and George Themistokleous (Eds). This Thing Called Theory (CRITIQUES: Critical Studies in Architectural Humanities, Vol. 12) (pp. 283-291). Abingdon \& New York: Routledge.

Stemshorn, M. (2002). Mies \& Schinkel: Das Vorbild Schinkels im Werk Mies van der Rohes. Berlin: Wasmuth.

Weiner, F. H. (1996). Towards the Tectonic: A Critique of the Idea of Space in Architectural Education. 84th ACSA Annual Meeting and Technology Conference Proceedings, 500-504.

-

Westheim, P. (1927). Mies van der Rohe. Entwicklung eines Architekten. Das Kunstblatt, 11(2), 55-62.

Zaera Polo, A. (2008). The Politics of the Envelope: A Political Critique of Materialism. Volume, 17(3), 76-105. 